\title{
$\boldsymbol{K} \boldsymbol{O E} \boldsymbol{R} S$
}

No. 11.

\section{DIE GRONDSLAE VAN DIE UNIE.}

Die huidige Uniefees bied die geleentheid, in besonder vir die Afrikaner, om hom opnuut rekenskap te gee van die basis van sy trou teenoor die Unie. Dit was lank die gebruik om die vraag van trou en lojaliteit as nie van toepassing op die Afrikaans-sprekende deel van die bevolking te beskou nie. Dit sou slegs geldig wees vir ons landgenote van Engelse herkoms. Vir baie jare het Afrikaners die houding ingeneem asof hulle 'n soort monopolie van die eienskappe van goeie burgerskap besit, of, ten minste, dit is stilswyend aanvaar. Miskien het ons 'n mate van reg gehad, gesien die omstandigheid van die langdurige verblyf van 'n Afrikaanssprekende volk in hierdie land, gespeen van politieke bande ten opsigte van 'n Europese moederland en gedra deur ' $n$ republikeinse erfenis.

Ons aanvaar dat die Afrikaanse volk gedurende die 18de eeu ontstaan het uit 'n vermenging van drie belangrike WesEuropese bestanddele, Hollands, Duits en Frans, hoewel die grondbestanddeel Hollands gebly het. Tog was daardie volk tot die koms van die Britte met die wending van die eeu nog 'n aanhangsel van Nederland en deel van die Nederlandse nasie (staatsvolk). Honderd en vyftig jaar na die landing van Van Riebeeck het die Afrikaanse volk nog nie gedroom van 'n selfstandige nasieskap nie. Anders as wat gewoonlik aangeneem word, was die sogenaamde republieke van Swellendam en GraaffReinet 'n illustrasie daarvan. Die woelinge in die grensdistrikte teen die einde van die 18de eeu lewer die oortuigende bewys dat die Afrikaners van daardie tyd wel teen die Kompanjie se bewind weerstand gebied en dit selfs verwerp het, maar terselfdertyd nog steeds trou en lojaliteit aan die Nederlandse moederland gesweer het. Dat die twee grensdistrikte ooit "republieke" was, is 'n blote legende wat op verkeerde bronnelesing deur die geskiedskrywer Theal berus. Waar die woord "republiek" in die dokumente voorkom, is dit met heenwys na die Verenigde Provinsies van Nederland, terwyl die uitdrukking ,President" bloot gebruik is om die voorsit- 
ter van die vergadering van verteenwoordigers aan te dui.

Die groot keerpunt het eers gekom toe die Britte die staatkundige band met Nederland eensklaps en met geweld verbreek het. Die Engelse verowering van die Kaap was in hierdie sin nie 'n onvermengde euwel nie, want dit het die Afrikaanse volk vroeër as wat waarskynlik was, in die geleentheid gestel om tot selfstandige nasieskap te ontwikkel, en dit nieteenstaande die staatkundige trou wat voortaan ten opsigte van 'n ander oorsese nasie geëis is. Die eerste geleentheid tot ontwikkeling in daardie rigting was die Groot Trek, toe ten minste 'n aansienlike deel van die volk sy nuwe lojaliteit afgesweer en 'n eie politieke en staatkundige eksperiment van stapal gestuur het. Die sigbare staatkundige resultaat van die Trek was die Boererepublieke in die binneland van Suid-Afrika. Dit was per slot van rekening 'n poging om die taalgrens en die staatsgrens identies te maak, m.a.w. om van die volk 'n nasie te maak maar, let wel, 'n eksklusiewe nasie. Die republikeinse geskiedenis van die Afrikaanse volk val tussen die twee pole van die Trek en die Tweede Vryheidsoorlog, wat die totstandkoming en ondergang respektiewelik van die Boerestate kenmerk. President Kruger se ganse strewe om die karakter van die Transvaalse republiek teen die opdringende Uitlanderdom te handhaaf, was 'n laaste, heldhaftige poging om ' $n$ aparte nasieskap in stand te hou. Daardie stryd is geaksentueer deurdat dit saamgeval het met 'n ongeëwenaarde imperialistiese druk om die hele Suid-Afrika Brits te maak. Die botsing is gesimbo- liseer in die figure van Kruger en Rhodes. Die einde was dat die droom van 'n eie, eksklusiewe Afrikaanse nasieskap vervlieg het in die vlamme en rook van tallose brandende Boerewonings.

Op 31 Mei 1902 het genl. J. C. Smuts op die groot kongres by Vereeniging waar verteenwoordigers van die twee republieke vir die laaste keer byeengekom het, in 'n toespraak wat selfs vandag na verloop van byna sestig jaar byna nie sonder aandoening gelees kan word nie, verklaar dat die Afrikaanse volk ontsaglike offers op die altaar van vryheid gelê het, maar dat die volk nie opgeoffer mag word vir 'n idee wat nie meer verwesenlik kan word nie. Hy het profeties daaraan toegevoeg dat die vryheidsoorlog per slot van rekening nie net ter wille van die Afrikaners gevoer is nie, maar vir die hele volk van SuidAfrika. Uit daardie oogpunt mag ons aflei, dat diegene wat die lewe in die oorlog gelaat het, nie net vir die republieke gesterf nie, maar vir 'n groter Suid-Afrika, waarin hulle hul ideale op 'n ruimer en ryker basis verwesenlik sou sien.

Die Groot Trek het die Afrikaners wel in staat gestel om 'n republikeinse tradisie op te bou, maar dit het ook 'n skadukant gehad deurdat dit die proses van balkanisering of staatkundige verbrokkeling van Suid-Afrika ingelui het. Ook dit is met die vrede van Vereeniging beëindig. Wat van Afrikaanse kant gesien, indertyd 'n ramp was, het later geblyk 'n bedekte seën te gewees het. Staatkundig en kultureel was dit die einde van die middelpuntvliedende magte in ons land. Die militêre neer- 
laag van die republieke het aan die een kant die bewys gelewer dat die ideaal van 'n Afrikaanse nasie, identies met die volk, nie meer verwesenlik kon word nie en dat binne die Suid-Afrikaanse nasionale raamwerk ook vir die ander blanke volk plek ingeruim moes word, en aan die ander kant het dit die begin valn 'n nuwe tydperk aangekondig, nl. 'n periode van staatkundige eenwording. Die offers wat die Afrikaanse volk vir hulle staatkundige ideale gebring het, was groot maar tevergeefs.

Maar wat het hulle nie gewen nie? 'n Gelouterde Afrikanerdom, hoewel uitgedun in getalle en stoflik verarm, het uit die stryd te voorsiryn getree met 'n veel sterker solidariteitsgevoel, met 'n nasionale trots en selfrespek wat luulle nie meer ontneem kon word nie en 'n geestelike eenheid wat ongetwyfeld 'n noodsaaklike voorwaarde vir die unifikasie van 1910 gevorm het. Nog meer, uit die gebeentes van die dooies het 'n nuwe geslag opgestaan wat die politieke en kulturele herlewing wat kort na 1902 ' $n$ aanvang geneem het, tot in ons eie tyd voortgesit het. Die begrafnis van president Kruger op 16 Desember 1904 het in die teken van die tyd gestaan. Sy stoflike reste is in Pretoria bygeset onder meegevoel van die hele volk en die respek van die eertydse vyand en teenstander. Sy liggaamlike oorblyfsels is in sy vaderland ontvang deur die hele volk en meteens was hy nie meer 'n Transvaler nie, maar die simbool van iets ruimers en groters. 'n Nuwe geslag het sy onwrikbare geloof in die herrysenis van sy volk op God se eie tyd geërf, en daardie geloof is ten dele gegrond op die trots op die verlede. 'n Verenigde Afrikanerdom kon met vertroue die Unie van Suid-Afrika as staatkundige tuiste aanvaar.

Die verlore oorlog het nie slegs die verbreiding van die nasionale gedagte moontlik gemaak nie, maar kultureel is die weg daartoe ook voorberei deur die 'Tweede Taalkeweging. In daardie opsig kon Eugene Marais se „Winternag” ewe goed die opskrif gedra het van ,Lenteruising". Die veredeling van die skryftaal was 'n noodsaaklike faset in die proses van nasionale bewuswording, en vir baie jare daarna was daar die allernouste verband tussen kultuur en politiek in die geestelike lewe van die Afrikaner.

Die breër konsepsic van nasieskap het sy staatkundige uitbouing en kulminasie gevind in die totstandkoming van die Unie, wat vir die eerste keer alle Afrikaners binne dieselfde nasionale raamwerk verenig het en daarby ook die Engelssprekendes. Wat laasgenoemdes betref, was dit 'n grootse kompromis tussen die twee uiterstes van Afrikaanse nasionale eksklusiwiteit en Britse imperialistiese oorheersing. Die Afrikaner het daarin ' $n$ baie groot offer gebring deur sy aparte nasieskap prys te gee en sy Staat te deel met die ander blanke bevolkingsgroep. Die groot gros van die Engelssprekendes wat lankal hierdie land as enigste vaderland aanvaar het, soos bewys deur hulle lidmaatskap van die Afrikanerbond in Kaapland, het ten minste in beginsel die Britse superioriteitsgedagte laat vaar. Die kompromis is beliggaam in artikel 137 van die Unie-grondwet insake die amptelike gelykheid van die twee tale wat, dieper gesien, die erkenning inhou 
van die toekomstige voortbestaan van twee volke met twee tale en twee kulture binne een en dieselfde nasionale verband. Dit was die prinsipiële grondslag waarop die Unie van Suid-Afrika tot stand gekom het.

Maar net so min as alle Engelstaliges het alle Afrikaners hulle harte aan die Unie oorgegee. Wel het genl. De Wet in 1909 op die Paarlberg verklaar dat hy elkeen wat teen die Unie was, met die seinkanon sou wegblaas. Dit kon nie verhinder dat baie Afrikaners nog gehunker het na die verlore republieke waarvan hulle die herinnering nie kon vernietig nie. Baie Engelssprekendes, en by name die Unioniste, het die Unie met die stilswyende voorbehoud aanvaar dat dit tog Brits sou wees en dat artikel 137 bloot 'n ,sop to Afrikaner sentiment" was. Hulle was staatkundig nog in Brittanje geanker en hulle het nog vas geglo in daardie ryk waar die son nooit ondergaan nie. Maar in die middel het ' $n$ soliede falanks SuidAfrikaners gestaan, verenig in genl. Botha se groot Suid-Afrikaanse Party waarin saamgesmelt is die Afrikaner Bond, „Het Volk” en die Oranje Unie van die Vrystaat. Dit was die partypolitieke draer van die nuwe nasionale gedagte.

Die verdere uitlewing van volle Suid-Afrikaanse nasieskap is van albei die uiterste kante vertraag. Die koppige teenkanting van die Unioniste en hulle latere Natalse geesgenote kon egter nie daarin slaag om die staatsregtelike vrywording van die Unie en die verkryging van die uitwendige simbole van nasieskap, soos 'n eie vlag en volkslied, te verhinder nie. Die nasionale proses is van die ander kant in die wiele gery deur te lank volgehoue smart oor gelede leed en onvergelde onreg. Selfs so laat soos 1919 het nie minder as geni. Hertzog nie nog 'n laaste poging in Versailles gaan aanwend om die onafhanklikheid van Transvaal en Vrystaat herstel te kry. Dit was geheel en al in stryd met die groot nasionale beginsels wat hy in 1912 baie suiwerder as genl. Botha verkondig en in Januarie 1914 in die program van die ou Nasionale Party vasgestel het.

Hierdie innerlike teenkanting teen die Unie bestaan in ' $n$ mate tot vandag nog, gelukkig nie meer in die geledere van die jong geslag wat nie meer die taal van hulle vaders spreek nie. Enige poging in die rigting van 'n Britse SuidAfrika is vooraf gedoern en enige begeerte om andermaal 'n soort Boererepubliek op te rig is onrealisties en die najaging van 'n skim. Die geskiedenis van 1910 het oortuigend bewys dat nog Cecil Rhodes nog Paul Kruger die oorwinning behaal het. As Afrikaners kan ons slegs dankbaar wees dat ons deur ons getalsterkte, ons politieke vernuf en ons eindelose geduld daarin geslaag het om die leeue-aandeel te kry. Daar kan geen twyfel meer bestaan nie wie vandag die substansie het en wie die skadu.

Vandag vra Suid-Afrika van sy Engelstalige burgers om te berus in die verbreking van die laaste politieke bande met hulle eertydse moederland cn die geesdriftige uitlewing van hulle Suid-Afrikaanse nasieskap saam met die Afrikanerdom. Maar Suid-Afrika vra 
ook van Afrikaanse kant die prysgawe van innerlike voorbehoude, en toewyding aan die ruimer nasionale gedagte, met ' $n$ gemoed vry van wrok indien nie vry van heimwee nie.

D. W. KRUGER. 